\title{
Correction to: Guy's and St Thomas NHS Foundation active surveillance prostate cancer cohort: a characterisation of a prostate cancer active surveillance database
}

Salonee Shah ${ }^{1 \dagger}$, Kerri Beckmann ${ }^{1,2 \dagger}$, Mieke Van Hemelrijck ${ }^{1}$, Ben Challacombe ${ }^{3}$, Rick Popert ${ }^{3}$, Prokar Dasgupta $^{3}$, Jonah Rusere ${ }^{3}$, Grace Zisengwe $^{3}$, Oussama Elhage ${ }^{3 \dagger}$ and Aida Santaolalla ${ }^{1{ }^{*}+}$

Correction to: BMC Cancer 21, 573 (2021)

https://doi.org/10.1186/s12885-021-08255-z

Following publication of the original article [1], the authors reported an omission from the funding statement. The correct funding statement is supplied below:

This work was supported by the department of Translational Oncology and Urology Research (TOUR) at King's College London, Medical Research Council Grant no: MR/R014043/1. The views expressed are those of the author(s) and the funding body had no role in the design of the study and collection, analysis, and interpretation of data in writing the manuscript. Kerri Beckmann is supported by national health and medical research council (NHMRC) ECR fellowship GNT 1124210.
Published online: 24 January 2022

\section{Reference}

1. Shah S, Beckmann K, Van Hemelrijck M, et al. Guy's and St Thomas NHS Foundation active surveillance prostate cancer cohort: a characterisation of a prostate cancer active surveillance database. BMC Cancer. 2021;21:573. https://doi.org/10.1186/s12885-021-08255-z.

\section{Author details}

'King's College London, School of Cancer and Pharmaceutical Sciences, Translational Oncology \& Urology Research (TOUR), London, UK. ${ }^{2}$ Cancer Research Institute, University of South Australia, Adelaide, Australia. ${ }^{3}$ King's College London \& Guy's and St Thomas' NHS Foundation Trust, London, UK.

The original article can be found online at https://doi.org/10.1186/s12885021-08255-z.

\footnotetext{
*Correspondence: aida.santaolalla@kcl.ac.uk

†'Salonee Shah and Kerri Beckmann contributed equally to this work.

${ }^{\dagger}$ Oussama Elhage and Aida Santaolalla are senior authors and contributed equally to this work.

1 King's College London, School of Cancer and Pharmaceutical Sciences,

Translational Oncology \& Urology Research (TOUR), London, UK

Full list of author information is available at the end of the article
}

(C) The Author(s) 2022. Open Access This article is licensed under a Creative Commons Attribution 4.0 International License, which permits use, sharing, adaptation, distribution and reproduction in any medium or format, as long as you give appropriate credit to the original author(s) and the source, provide a link to the Creative Commons licence, and indicate if changes were made. The images or other third party material in this article are included in the article's Creative Commons licence, unless indicated otherwise in a credit line to the material. If material is not included in the article's Creative Commons licence and your intended use is not permitted by statutory regulation or exceeds the permitted use, you will need to obtain permission directly from the copyright holder. To view a copy of this licence, visit http://creativecommons.org/licenses/by/4.0/. The Creative Commons Public Domain Dedication waiver (http://creativeco mmons.org/publicdomain/zero/1.0/) applies to the data made available in this article, unless otherwise stated in a credit line to the data. 